\title{
MCC wt Allele
}

National Cancer Institute

\section{Source}

National Cancer Institute. MCC wt Allele. NCI Thesaurus. Code C54309.

Human MCC wild-type allele is located in the vicinity of 5q21-q22 and is approximately $360 \mathrm{~kb}$ in length. This allele, which encodes colorectal mutant cancer protein, may play a role in tumor suppression. MCC wild-type allele is a candidate colorectal tumor suppressor gene. 